\title{
The glycosylation of the aspartic proteinases from barley (Hordeum vulgare L.) and cardoon (Cynara cardunculus $\mathbf{L}$.)
}

\author{
Júlia COSTA ${ }^{1,2}$, David A. ASHFORD ${ }^{3}$, Manfred NIMTZ ${ }^{4}$, Isabel BENTO ${ }^{\prime}$, Carlos FRAZÃO ${ }^{1}$, Cristina L. ESTEVES ${ }^{\circ}$, Carlos J. FARO $^{\dagger}$, \\ Jukka KERVINEN ${ }^{5}$, Euclides PIRES ${ }^{\circ}$, Paula VERÍSSIMO ${ }^{\circ}$, Alexander WLODAWER ${ }^{5}$ and Maria Arménia CARRONDO ${ }^{1.7}$ \\ 1 Instituto de Tecnologia Química e Biológica, Universidade Nova de Lisboa, Oeiras, Portugal \\ Instituto de Biologia Experimental e Tecnológica, Oeiras, Portugal \\ Plant Glycoprotein Research Facility, The Plant Laboratory, Department of Biology, University of York, UK \\ Department of Molecular Instrumental Structure Research, Gesellschaft für Biotechnologische Forschung mBH, Braunschweig, Germany \\ Macromolecular Structure Laboratory, NCI-Frederick Cancer Research and Development Center, ABL-Basic Research Program, \\ Frederick MD, USA \\ - Departamento de Bioquímica, Faculdade de Ciências e Tecnologia, Universidade de Coimbra, Portugal \\ Instituto Superior Técnico, Lisboa, Portugal
}

(Received 5 August/15 November 1996) - EJB 96 1163/5

Plant aspartic proteinases characterised at the molecular level contain one or more consensus $\mathrm{N}$ glycosylation sites [Runeberg-Roos, P., Törmäkangas, K. \& Östman, A. (1991) Eur. J. Biochem. 202, 1021-1027; Asakura, T., Watanabe, H., Abe, K. \& Arai, S. (1995) Eur. J. Biochem. 232, 77-83; Veríssimo, P., Faro, C., Moir, A. J. G., Lin, Y., Tang, J. \& Pires, E. (1996) Eur. J. Biochem. 235, 762-768]. We found that the glycosylation sites are occupied for the barley (Hordeum vulgare L.) aspartic proteinase (Asn333) and the cardoon (Cynara cardunculus L.) aspartic proteinase, cardosin A (Asn70 and Asn363). The oligosaccharides from each site were released from peptide pools by enzymatic hydrolysis with peptide-N-glycanase A or by hydrazinolysis and their structures were determined by exoglycosidase sequencing combined with matrix-assisted laser desorption/ionization time of flight mass spectrometry. It was observed that $6 \%$ of the oligosaccharides from the first glycosylation site of cardosin A are of the oligomannose type. Modified type glycans with proximal Fuc and without Xyl account for about $82 \%$, $14 \%$ and $3 \%$ of the total oligosaccharides from the first and the second glycosylation sites of cardosin $\mathrm{A}$ and from $H$. vulgare aspartic proteinase, respectively. Oligosaccharides with Xyl but without proximal Fuc were only detected in the latter proteinase $(4 \%)$. Glycans with proximal Fuc and Xyl account for $6 \%, 86 \%$ and $92 \%$ of the total oligosaccharides from the first and second glycosylation sites of cardosin A and from $H$. vulgare aspartic proteinase, respectively.

Keywords: aspartic proteinase; Cynara cardunculus; glycosylation; Hordeum vulgare.

Aspartic proteinases (EC 3.4.23) are a class of endopeptidases with acidic $\mathrm{pH}$ optima that are inhibited by pepstatin $\mathrm{A}$. They are present in a wide variety of organisms such as viruses, fungi, plants and animals. They are highly similar among species with a conserved three-dimensional structure consisting of two lobes with a deep and extended substrate-binding cleft. The cleft has two conserved Asp residues (32 and 215 in pepsin numbering) that are essential for catalytic activity (Davies, 1990).

In plants, an inserted sequence of approximately 100 amino acids separates the homologous aspartic proteinase sequences into two regions (Runeberg-Roos et al., 1991; Cordeiro et al., 1994; Asakura et al., 1995). Although this plant-specific insert

Correspondence to J. Costa, Instituto de Tecnologia Química e Biológica, Universidade Nova de Lisboa, Apart. 12, P-2780 Oeiras, Portugal

Fax: + 35114411277

Abbreviations. CA31 and CA15, 31-kDa and 15-kDa subunits of cardosin A, respectively; ConA, concanavalin A; HvAP, Hordeum vulgare aspartic proteinase; MALDI/TOF-MS, matrix-assisted laser-desorption/ionization time-of-flight mass spectrometry; PNGase A, peptide-N-glycanase A; PNGase F, peptide- $\mathrm{N}$-glycanase $\mathrm{F}$.

Enzymes. Aspartic proteinases (EC 3.4.23); $\alpha$-mannosidase $(\mathrm{EC}$ 3.2.1.24); $\beta$-mannosidase (EC 3.2.1.25); $\beta$ - $N$-acetylhexosaminidase (EC 3.2.1.52); $\beta$-galactosidase (EC 3.2.1.23); $\alpha$-L-fucosidase (EC 3.2.1.51); peptide-N-glycanase $\mathrm{F}$ (EC 3.5 .1 .52 ). has no similarity to animal or microbial aspartic proteinases, it has recently been noticed to be highly similar to saposins, sphingolipid-activating proteins from mammalian cells. This similarity includes six conserved cysteines, an N-glycosylation site, the hydrophobicity pattern, and an invariant Tyr55 residue (Guruprasad et al., 1994; Ponting and Russell, 1995). Glycosylation sites have also been identified outside the plant-specific region in aspartic proteinases from different sources (e.g. Metcalf and Fusek, 1993). The glycosylation of aspartic proteinases may have a role in the stabilization of the enzymes, as found for recombinant renin expressed in COS cells (Hori et al., 1988), or in their secretion, as found for the recombinant aspartic proteinase from Mucor expressed in yeast (Aikawa et al., 1990).

Barley (Hordeum vulgare L.) aspartic proteinase (HvAP) has been characterized at the physiological and molecular levels (Törmäkangas et al,, 1994, and references therein). Based on the cDNA-derived primary structure of HvAP (Runeberg-Roos et al., 1991), the 48-kDa enzyme form contains a single $\mathrm{N}$-glycosylation site located in the plant-specific region of the $16-\mathrm{kDa}$ subunit. The cardoon (Cynara cardunculus L.) aspartic proteinase, cardosin A, has two glycosylation sites, one in the $15-\mathrm{kDa}$ subunit and another in the 31-kDa subunit (Veríssimo et al., 1996). Cardosin A is a cardoon enzyme of particular importance 
due to its use in cheese production in Portugal (Macedo et al., 1993). In this paper we present detailed characterization of the glycans of HvAP and of each site of cardosin A.

\section{MATERIALS AND METHODS}

Materials. Fresh flowers of Cynara cardunculus L. were collected from plants grown from seeds supplied by the Botanical Gardens of the University of Coimbra. Dry barley (Hordeum vulgare L. cv. Kustaa) grains were supplied by the Biotechnology and Food Research Laboratory, Technical Research Centre of Finland, Espoo.

Enzyme purification. The purification of cardosin $A$ and the separation of the corresponding $31-\mathrm{kDa}$ (CA31) and $15-\mathrm{kDa}$ (CA15) subunits were performed as previously described (Veríssimo et al., 1996). Barley aspartic proteinase was purified from ground grains by affinity chromatography on a pepstatin-agarose column followed by anion-exchange chromatography (Sarkkinen et al., 1992).

Protein analysis. Proteins were separated by SDS/PAGE according to Laemmli (1970) and detected with Coomassie R-250 or by silver staining. The transfer from the gels to polyvinylidenedifluoride membranes was performed in a semi-dry apparatus (Bio-Rad) following the supplier's indications. The detection of glycoproteins on blot with peroxidase-conjugated concanavalin A (ConA), $1 \mathrm{mg} / \mathrm{ml}$ Ricinus communis agglutinin, $1 \mathrm{mg} /$ $\mathrm{ml}$ Tetragonolobus purpureas lectin and $1 \mathrm{mg} / \mathrm{ml}$ Helix aspersa lectin were performed according to Faye and Chrispeels (1985). Protein concentration was measured according to Bensadoun and Weinstein (1976).

Oligosaccharide release. Peptides from each of the subunits of cardosin A (approximately $1 \mathrm{mg}$ each) were produced by hydrolysis with pronase E (Sigma) (Montreuil et al., 1986) and the corresponding oligosaccharides were released with $15 \mathrm{mU} / \mathrm{ml}$ peptide-N-glycanase A (PNGase A; Seikagaku Co.) in $0.01 \mathrm{M}$ sodium acetate $\mathrm{pH} 5.1$ containing $1.6 \mathrm{mM}$ phenylmethylsulfonyl fluoride and $16 \mu \mathrm{M}$ pepstatin $\mathrm{A}$, at $37^{\circ} \mathrm{C}$ for $24 \mathrm{~h}$. The pronase peptide pool was separated by reverse-phase HPLC on a $\mathrm{C} 18$ column as described by Grabenhorst et al. (1993) before and after PNGase A incubation. After enzyme treatment, orcinolpositive fractions associated with peptide were no longer detected and a new orcinol-positive peak appeared at the void volume of the column which indicated that the glycopeptides had been successfully deglycosylated with PNGase A. These glycan pools were subsequently desalted by ion-exchange procedures (Ashford et al., 1987), and labelled with 2-aminobenzamide (Signal labelling kit, Oxford GlycoSystems) according to the method of Bigge et al. (1995). Additionally the glycans were released from purified CA31 and CA15 (approximately $1 \mathrm{mg}$ each), and from HvAP (approximately $200 \mu \mathrm{g}$ ) by automated hydrazinolysis (GlycoPrep 1000, Oxford GlycoSystems) at $95^{\circ} \mathrm{C}$ for $5 \mathrm{~h}$, or at $85^{\circ} \mathrm{C}$ for $7 \mathrm{~h}$. The resulting glycan pools were labelled with 2-aminobenzamide as described above.

CA31 and CA15 $(2 \mu \mathrm{g})$ were incubated with PNGase A for 3 days at $37^{\circ} \mathrm{C}$ under the following conditions: (a) $12 \mathrm{mU} / \mathrm{ml}$, non-denaturing conditions in $60 \mathrm{mM}$ citrate/phosphate $\mathrm{pH} 5.0$ containing $1 \mathrm{mM}$ phenylmethylsulfonyl fluoride, $1 \mu \mathrm{M}$ pepstatin A (total volume $33.2 \mu \mathrm{l}$ ); (b) $12 \mathrm{mU} / \mathrm{ml}$, denaturing conditions in $20 \mu \mathrm{l} 60 \mathrm{mM}$ citrate/phosphate pH 5.0 containing $0.1 \%$ (mass/vol.) SDS and 0.1 M 2-mercaptoethanol, the protein was boiled for 3 min after which $5 \mu 110 \%$ (mass/vol.) Nonidet P-40 was added followed by the PNGase $\mathrm{A}$ and the protease inhibitors; (c) $33 \mathrm{mU} / \mathrm{ml}$, non-denaturing conditions in $0.01 \mathrm{M}$ sodium acetate $\mathrm{pH} 5.1$ containing protease inhibitors as indicated above (Tarentino and Plummer, 1982).
CA31 and CA15 were incubated with $100 \mathrm{mU} / \mathrm{ml}$ peptideN-glycanase F (PNGase F, Oxford GlycoSystems) under denaturing and non-denaturing conditions following the protocol indicated by the suppliers. Ribonuclease $B$ was used as a positive control for PNGase F deglycosylation. Deglycosylation with trifluoromethanesulfonic acid was performed according to Edge et al. (1981).

Gel filtration of the oligosaccharides and exoglycosidase sequencing. The 2-aminobenzamide-labelled glycans were separated by gel filtration using a RAAM 2000 Glycosequencer (Oxford GlycoSystems). Dextran hydrolysate was used as the calibration standard. Labelled oligosaccharides were hydrolyzed sequentially with specific glycosidases. The enzymes Aspergillus saitoi $\alpha 2$-mannosidase, Helix pomatia $\beta 4$-mannosidase, $\mathrm{Ca}$ navalia ensiformis (jack bean) $\beta$-hexosaminidase and $\beta 4$-galactosidase were obtained from Oxford GlycoSystems and used according to the supplier's instructions. The Charonia lampas $\alpha$ fucosidase (Seikagaku Co.) was used at a $7 \mathrm{mU} / \mathrm{ml}$ concentration in $10 \mathrm{mM}$ sodium acetate $\mathrm{pH} 4.5$ containing $0.15 \mathrm{M} \mathrm{NaCl}$ and $0.02 \%$ (mass/vol.) sodium azide. The $C$. ensiformis $\alpha$-mannosidase was a gift of Dr Terry Butters (Oxford Glycobiology Institute) and was used at $50 \mathrm{U} / \mathrm{ml}$ in $10 \mathrm{mM}$ sodium acetate $\mathrm{pH} 4.5$. Nicotiana tabacum $\beta$-xylosidase (Khan and Ashford, 1996, unpublished results) was used at $30 \mathrm{mU} / \mathrm{ml}$ in $0.1 \mathrm{M}$ sodium acetate $\mathrm{pH} 4.5$. One unit of glycosidase is defined as the amount of enzyme that catalyzed the release of $1 \mu \mathrm{mol} 4$-nitrophenol from the relevant 4-nitrophenyl glycoside/min at $37^{\circ} \mathrm{C}$. The incubations were performed for $18 \mathrm{~h}$ at $37^{\circ} \mathrm{C}$, and were terminated by heating at $100^{\circ} \mathrm{C}$ for $3 \mathrm{~min}$. Protein and salts were removed from samples by ion-exchange procedures (Ashford et al., 1987).

Matrix-assisted laser-desorption/ionization time-of-flight mass spectrometry (MALDI/TOF-MS). 2,5-Dihydroxybenzoic acid $(10 \mathrm{mg} / \mathrm{ml})$ was used as the ultraviolet-absorbing matrix in $10 \%$ aqueous ethanol. Solutions of the 2-aminobenzamide-labelled oligosaccharides in methanol were mixed with an equal volume of matrix; $1 \mu \mathrm{l}$ of the mixture was spotted onto a stainless steel tip and dried at room temperature. The concentration of the analytes were approximately $10 \mu \mathrm{M}$. Measurements were performed on a Brucker REFLEXTM MALDI/TOF mass spectrometer using a $\mathrm{N}_{2}$ laser $(337 \mathrm{~nm})$ with 3-ns pulse width and $107-108 \mathrm{~W} / \mathrm{cm}^{2}$ irradiance at the surface $\left(0.2-\mathrm{mm}^{2}\right.$ spot). Spectra were recorded at an acceleration voltage of $20 \mathrm{kV}$ using the reflectron for enhanced resolution.

\section{RESULTS}

Oligosaccharide release. The $31-\mathrm{kDa}$ and $15-\mathrm{kDa}$ subunits of cardosin A (CA31 and CA15) and HvAP were analysed by SDS/ PAGE. Both subunits of cardosin A and the 16-kDa subunit of HvAP were detected on blots with ConA showing that all the glycosylation sites are occupied. The ConA-positive polypeptides were not detected on blots with $R$. communis, $H$. aspersa or $T$. purpureas lectins which indicates that these polypeptides do not contain significant amounts of the $N$-acetylactosaminetype glycans or glycans with peripheral Gal or Fuc residues.

PNGase F was used as a first attempt to release the glycans from the polypeptides. However, with the exception of a low percentage of CA31 that was sensitive to the enzyme, no significant deglycosylation was observed. This suggested that the glycans from both enzymes were of the plant-modified type with Fuc $\alpha 1,3$ linked to the innermost GlcNAc. It was further observed that the intact polypeptides were not deglycosylated by PNGase A under a variety of conditions. The glycans were released from pronase $\mathrm{E}$ peptide pools of CA31 and CA15 by PNGase A. The released glycans were then labelled with 2 - 


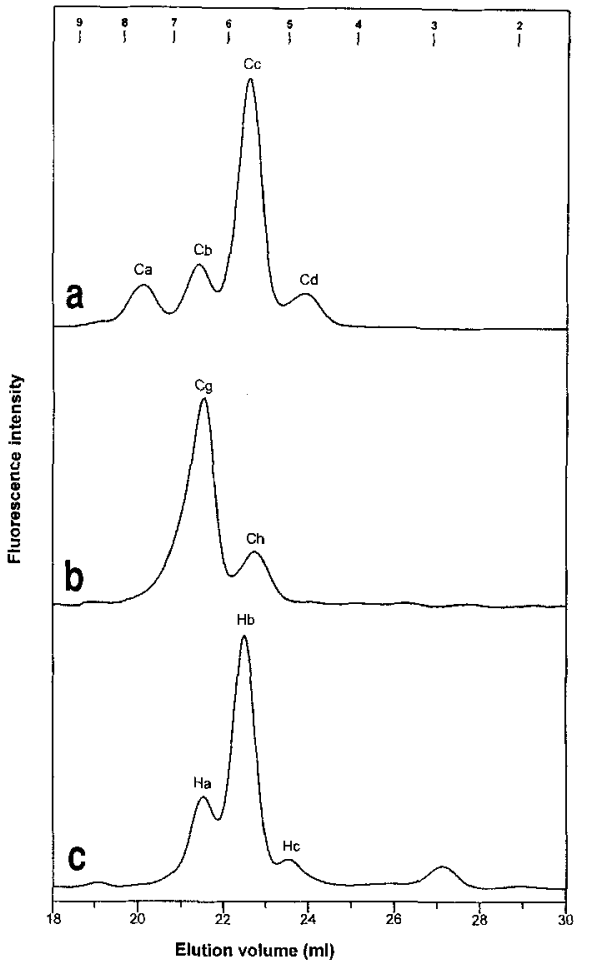

Fig. 1. Gel filtration analysis of the oligosaccharides from CA31 (a), CA15 (b) and HvAP (c). The oligosaccharides were released from CA31 and CA15 pronase peptides with PNGase A and from HvAP by hydrazinolysis, and were separated by high-resolution gel filtration into the components $\mathrm{Ca}-\mathrm{d}, \mathrm{g}$ and $\mathrm{h}$, and $\mathrm{Ha}-\mathrm{c}$, respectively. The elution positions of glucose and isomaltooligosaccharides containing the corresponding number of glucose units are indicated at the top. The hydrodynamic volumes of components $\mathrm{Ca}-\mathrm{g}$ and $\mathrm{Ha}-\mathrm{c}$ are $7.6,6.5,5.7,4.8$, $6.5,5.7,6.4,5.7$ and 5.0 glucose units, respectively.

aminobenzamide and separated according to hydrodynamic volume by gel filtration. The elution profiles obtained are shown in Fig. 1 ( $\mathrm{a}$ and $\mathrm{b}$ ); the number $(n)$ of glucose units given below indicates the elution position relative to glucose oligomers, $\mathrm{Glc}_{n}$. Major components at 7.6, 6.5, 5.7 and 4.8 glucose units were obtained for CA31 $(\mathrm{Ca}-\mathrm{Cd}$, respectively), and at 6.5 and 5.7 glucose units for $\mathrm{CA} 15(\mathrm{Cg}$ and $\mathrm{Ch})$. Since pronase E proteolysis is non-specific and since PNGase A activity depends on the oligosaccharide structures and the length of the corresponding glycopeptides, we also used automated hydrazinolysis at $95^{\circ} \mathrm{C}$ for $5 \mathrm{~h}$ to release the oligosaccharides. Essentially similar profiles to those shown in Fig. $1(\mathrm{a}, \mathrm{b})$ were obtained by this method of release with the following exceptions: for CA31 three new minor components at $9.8(3 \%), 4.3(5 \%)$ and at $3.0(12 \%)$ glucose units appeared after hydrazinolysis, and the component at 4.8 glucose units was no longer detected; for CA15 a new component at 3.6 glucose units appeared. Furthermore, when the hydrazinolysis conditions were changed to $85^{\circ} \mathrm{C}$ for $7 \mathrm{~h}$, it was observed that for CA31 the component at 4.3 glucose units was no longer detected and the component at 3.0 glucose units was decreased to approximately $6 \%$.

HvAP glycans were released by automated hydrazinolysis at $85^{\circ} \mathrm{C}$ for $7 \mathrm{~h}$, fluorescently labelled and separated as described above (Fig. 1c). Major components at 6.4, 5.7, 5.0 $(\mathrm{Ha}-\mathrm{Hc}$ ) and 2.9 glucose units were detected.

Oligosaccharide structures. In order to determine the structure of the oligosaccharides, two complementary approaches were followed: exoglycosidase sequencing and analysis by gel filtration, and MALDI/TOF-MS. The molecular masses determined
Table 1. Molecular masses and composition of the components from gel filtration pools of 2-aminobenzamide labelled oligosaccharides from CA31 and HvAP (Fig. 1, a and c). Hex, hexose; Pent, pentose.

\begin{tabular}{|c|c|c|c|}
\hline Protein & Pool & $\begin{array}{l}\text { Molecular } \\
\text { mass }\end{array}$ & Composition \\
\hline \multirow[t]{4}{*}{ CA31 } & $\mathrm{Ca}$ & $\begin{array}{l}1404 \\
1420^{a} \\
1526\end{array}$ & 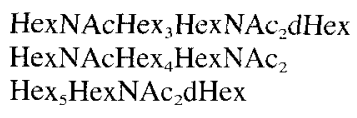 \\
\hline & $\mathrm{Cb}$ & $\begin{array}{l}1243 \\
1333 \\
1364 \\
1379\end{array}$ & $\begin{array}{l}\text { HexNAcHex } \mathrm{HexNAc}_{2} \mathrm{dHex} \\
\text { PentHex } \mathrm{HexNAc}_{2} \mathrm{dHex}_{3} \\
\mathrm{Hex}_{4} \mathrm{HexNAc}_{2} \mathrm{dHex} \\
\mathrm{Hex}_{5} \mathrm{HexNAc}_{2}\end{array}$ \\
\hline & $\mathrm{Cc}$ & $\begin{array}{l}1201 \\
1217^{a}\end{array}$ & $\begin{array}{l}\mathrm{Hex}_{3} \mathrm{HexNAc}_{2} \mathrm{dHex} \\
\mathrm{Hex}_{4} \mathrm{HexNAc}_{2}\end{array}$ \\
\hline & $\mathrm{Cd}$ & 1055 & $\mathrm{Hex}_{3} \mathrm{HexNAc}_{2}$ \\
\hline \multirow[t]{2}{*}{ HvAP } & $\mathrm{Ha}$ & $\begin{array}{l}1333 \\
1378\end{array}$ & $\begin{array}{l}\text { PentHex }{ }_{3} \mathrm{HexNAc}_{2} \mathrm{dHex} \\
\mathrm{Hex}_{5} \mathrm{HexNAc}_{2}\end{array}$ \\
\hline & $\mathrm{Hb}$ & 1169 & PentHex $_{2} \mathrm{HexNAc}_{2} \mathrm{dHex}$ \\
\hline
\end{tabular}

a These molecular masses are identical to that of the potassium adduct from the previous peak.

by MALDI/TOF-MS and their possible composition are shown in Table 1.

Oligosaccharides of the oligomannose type composed a significant fraction in CA31 but were only detected in minor amounts in CA15 and HvAP. The oligomannose glycans account for about $6 \%$ of the total oligosaccharides of CA 31 and probably correspond to the fraction of CA31 that was deglycosylated with PNGase F. Oligosaccharides $\mathrm{Cb} 4, \mathrm{Cc} 2, \mathrm{Cd} 2, \mathrm{Cg} 3, \mathrm{Ha} 3, \mathrm{Hb} 4$ and $\mathrm{Hc} 3$ were hydrolyzed with jack bean $\alpha$-mannosidase and lost 4 , $3,2,4,4,3$ and 2 glucose units, respectively, producing a component that eluted at 3.2 glucose units; oligosaccharide $\mathrm{Cb} 4$ was further hydrolysed with $H$. pomatia $\beta 4$-mannosidase producing a 2.1 glucose units component that co-eluted with authentic labelled GlcNAc/34GlcNAc. Molecular masses of 1379, 1217 , 1055 and 1378 Da corresponding to $\mathrm{Cb} 4, \mathrm{Cc} 2, \mathrm{Cd} 2$ and $\mathrm{Ha} 3$, respectively, were also determined by MALDI/TOF-MS (Table 1). Component $\mathrm{Ca} 3$ was sequentially hydrolyzed with jack bean $\beta$-hexosaminidase and jack bean $\alpha$-mannosidase and lost 2 and 3 glucose units, respectively; a molecular mass of 1420 Da consistent with the structure HexNAcHex ${ }_{4} \mathrm{HexNAc}_{2}$ was detected by MALDI/TOF-MS. On the basis of these results and the known N-glycosylation biosynthetic pathway, the proposed structures for these oligosaccharides are shown in Fig. 2. The minor component of CA31 at 9.8 glucose units only released by hydrazinolysis was shown to be highly heterogeneous. Approximately half of it was of the oligomannose type $\mathrm{Man}_{8} \mathrm{GlcNAc}_{2}$ since it lost 3 and 4 glucose units after hydrolysis with $A$. saito $i$ $\alpha 2$-mannosidase and jack bean $\alpha$-mannosidase, respectively, the final product migrating at 3.2 glucose units.

Oligosaccharides of the plant modified type with proximal Fuc $\alpha 1,3$ but without Xyl were identified in both subunits of cardosin A and in HvAP. Oligosaccharides Ca1, Cb3, Cc1, Cd1, $\mathrm{Cg} 2, \mathrm{Ch} 2, \mathrm{Ha} 2$ and $\mathrm{Hb} 3$ were hydrolyzed with jack bean $\alpha$ mannosidase and all eluted at 3.9 glucose units, indicating the hydrolysis of 4, 3, 2, 1, 3, 2, 3 and 2 Man residues, respectively. The oligosaccharides $\mathrm{Ca} 1, \mathrm{Cb} 3, \mathrm{Cc} 1, \mathrm{Cg} 2, \mathrm{Ch} 2, \mathrm{Ha} 2$ and $\mathrm{Hb} 3$ were further hydrolyzed with $\mathrm{H}$. pomatia $\beta 4$-mannosidase resulting in a decrease of hydrodynamic volume to 2.9 glucose units, the position of authentic labelled GlcNAc $\beta 4$ (Fuc $\alpha 3$ )GlcNAc. The oligosaccharide $\mathrm{Ca} 2$ was sequentially hydrolysed with jack 

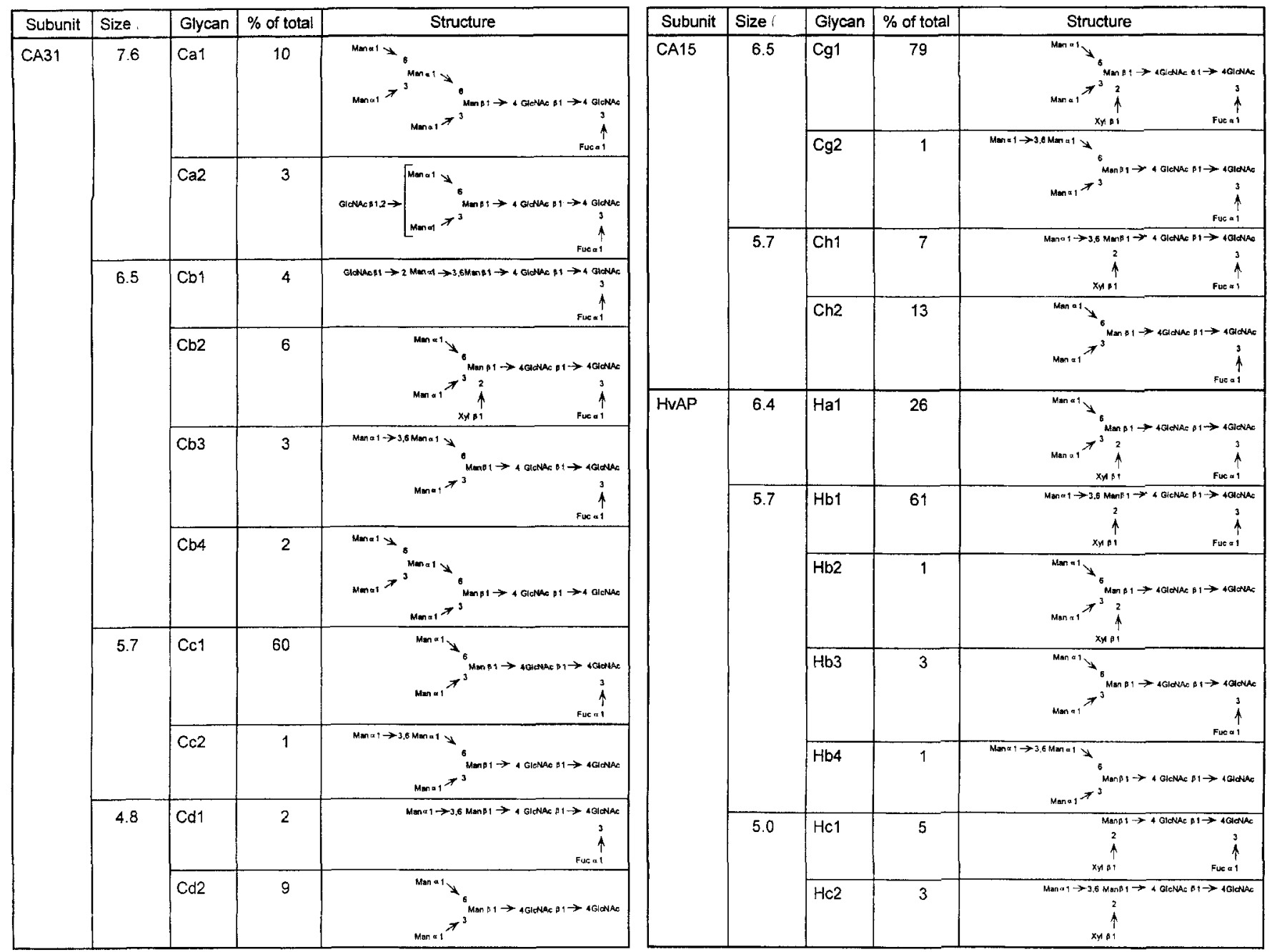

Fig. 2. The proposed structures of the major oligosaccharides of cardosin A and HvAP. The size is given in glucose units.

bean hexosaminidase and jack bean $\alpha$-mannosidase with hydrodynamic volume decreases of 2 glucose units each. By MALDI/TOF-MS masses of 1404, 1526, 1364 and 1201 Da corresponding to the components $\mathrm{Ca} 2, \mathrm{Ca} 1, \mathrm{Cb} 3$ and $\mathrm{Cc} 1$, respectively, were determined (Table 1). Component $\mathrm{Cb} 1$ has a molecular mass of $1243 \mathrm{Da}$ (Table 1) consistent with the structure HexNAcHex ${ }_{2} \mathrm{HexNAc}_{2} \mathrm{dHex}$. The proposed structures for these components are shown in Fig. 2. The modified type glycans with proximal Fuc and without Xyl account for about $82 \%, 14 \%$, and $3 \%$ of the total oligosaccharides of CA31, CA15 and HvAP, respectively. Oligosaccharides of the plant modified type with proximal Fuc and terminal GlcNAc but without Xyl were only detected in $\mathrm{CA} 31$ ( $\mathrm{Ca} 2$ and $\mathrm{Cb} 1)$ where they account for $7 \%$ of the total oligosaccharides.

Oligosaccharides of the plant modified type with $\mathrm{Xyl}$ but without proximal Fuc were only detected in HvAP. Components $\mathrm{Hb} 2$ and $\mathrm{Hc} 2$ lost 2 and 1 glucose units, respectively, after incubation with jack bean $\alpha$-mannosidase and were not sensitive to H. pomatia $\beta$-mannosidase. Their proposed structure is shown in Fig. 2. They account for about $4 \%$ of the HvAP oligosaccharides.

Oligosaccharides of the plant modified type with proximal Fuc and Xyl were identified in both subunits of cardosin $\mathrm{A}$ and in HvAP. Oligosaccharides $\mathrm{Cb} 2, \mathrm{Cg} 1, \mathrm{Ch} 1, \mathrm{Ha} 1, \mathrm{Hb} 1$ and $\mathrm{Hc} 1$ were hydrolyzed with jack bean $\alpha$-mannosidase and lost 2, 2, 1, 2, 1 and 0 Man residues, respectively, the final product migrating at 5.0 glucose units in all cases. When the product of oligosaccharide $\mathrm{Cb} 2$ was sequentially incubated with $N$. tabaccum $\beta$ xylosidase and $H$. pomatia $\beta 4$-mannosidase, its hydrodynamic volume decreased successively to 3.9 and 2.9 glucose units, the positions of labelled Man $\beta 4$ GlcNAc $\beta 4($ Fuc $\alpha 3)$ GlcNAc and GlcNAc $\beta 4(\operatorname{Fuc} \alpha 3)$ GlcNAc, respectively. The products of Ha1 and $\mathrm{Hb} 1$ after incubation with $N$. tabaccum $\beta$-xylosidase both migrated at 3.9 glucose units. After successive incubations with $C$. lampas $\alpha$-fucosidase and $N$. tabaccum $\beta$-xylosidase the oligosaccharide $\mathrm{Cg} 1$ migrated at 4.3 and 3.2 glucose units, the positions of labelled Xyl $\beta 2 \mathrm{Man} \beta 4 \mathrm{GlcNAc} \beta 4$ (Fuc $\alpha 3$ )GlcNAc and Man $\beta 4$ GlcNAc $\beta 4$ (Fuc $\alpha 3$ )GlcNAc, respectively. Components of 1333, 1333 and $1169 \mathrm{Da}$, corresponding to $\mathrm{Cb} 2, \mathrm{Ha} 1$ and $\mathrm{Hb} 1$, respectively, were detected by MALDI/TOF-MS (Table 1). The proposed structures for these oligosaccharides are shown in Fig. 2. The modified type glycans with proximal Fuc and Xyl account for approximately $6 \%, 86 \%$ and $92 \%$ of the total oligosaccharides of CA31, CA15 and HvAP, respectively.

After the oligosaccharides were released by hydrazinolysis the components at 4.3 and 3.0 glucose units from CA31, at 3.6 glucose units from CA15 and at 2.9 glucose units from HvAP were sequenced with exoglycosidases and/or their masses were determined by MALDI/TOF-MS. These components were shown to consist mostly of hydrazinolysis degradation products of the corresponding major oligosaccharides where the linkage between the two GlcNAc residues of the core was cleaved. 

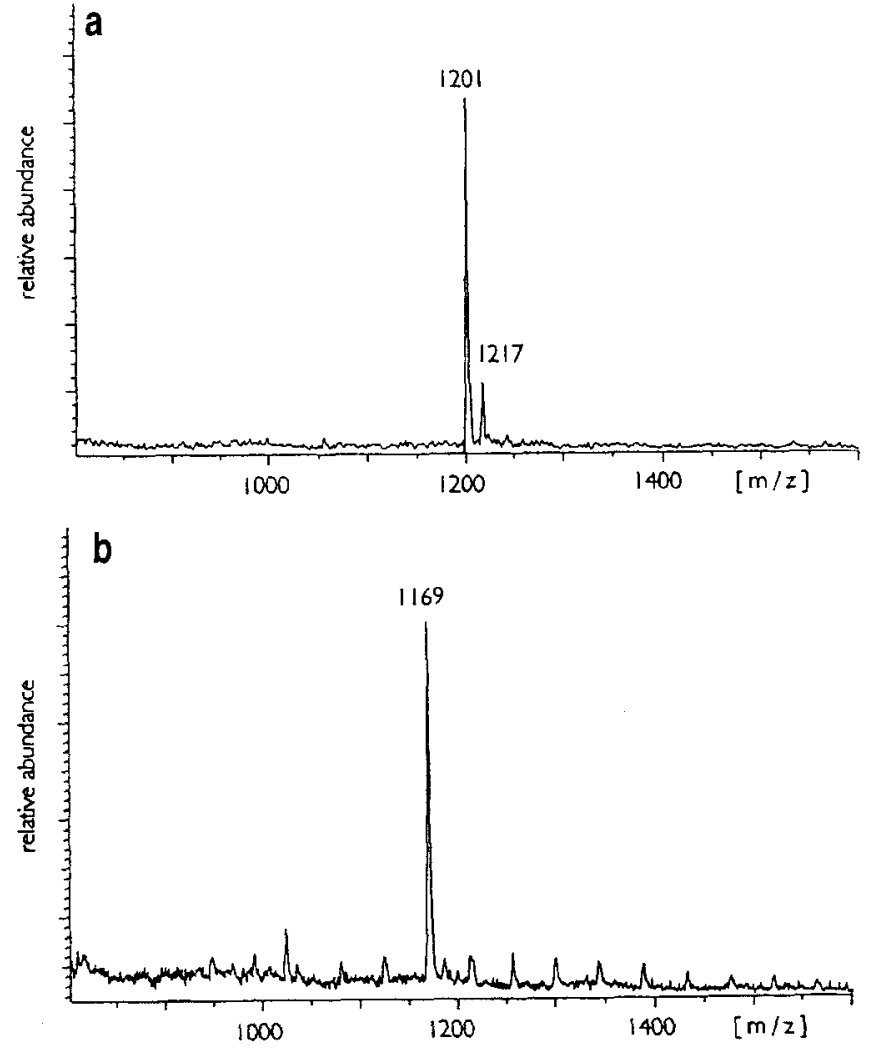

Fig. 3. Matrix-assisted laser-desorption/ionization time-of-flight mass spectrometry of the components Ce from CA31 (a) and $\mathrm{Hb}$ from HvAP (b).

\section{DISCUSSION}

The major oligosaccharides in both subunits of cardosin A and of HvAP are of the plant modified type. For cardosin A the oligosaccharides were released from the protein by enzymatic hydrolysis with PNGase A and by hydrazinolysis. The major components at 5.7 glucose units for CA31 and at 6.5 and 5.7 glucose units for CA15 were obtained by both techniques which indicates that they are not artifacts. The minor component at 9.8 glucose units $(3 \%)$ released from CA31 by hydrazinolysis and not by PNGase hydrolysis suggests a limitation of the enzyme's specificity for the release of this type of glycan (mostly $\mathrm{Man}_{8} \mathrm{GlcNAc}_{2}$ ). It has previously been found that hydrazinolysis can lead to cleavage between the two core GlcNAc residues of plant glycans when the reducing terminal residue is substituted with an $\alpha 3$-linked Fuc (Hase et al., 1986; van Kuik et al., 1986; Ashford et al., 1987). Similarly we observed that the release of the oligosaccharides of CA31 and CA15 by automated hydrazinolysis at $95^{\circ} \mathrm{C}$ for $5 \mathrm{~h}$ (manufacturer's $\mathrm{N}+\mathrm{O}$ mode) caused $25 \%$ degradation of the major oligosaccharides at 5.7 glucose units for CA31 and 6.5 glucose units for CA15, with products at 3.0 and 3.6 glucose units, respectively. However, we were able to decrease the degradation to $6 \%$ by altering the hydrazinolysis conditions to $85^{\circ} \mathrm{C}$ for $7 \mathrm{~h}$. This shows that optimization of the hydrazinolysis conditions for the release of plant modified type glycans using the GlycoPrep instrument is necessary to minimize degradation.

For CA15 and HvAP the oligosaccharides contain both $\beta 1,2-$ linked Xyl and $\alpha 1,3$-linked Fuc, whereas for CA31 the majority of the modified type contain only the proximal Fuc residue. This is clearly shown in Fig. 3 where the major oligosaccharides of CA31 and HvAP, which both migrate at 5.7 glucose units on gel filtration, are analysed by MALDI/TOF-MS. The peaks at 1201 and $1169 \mathrm{Da}$ correspond to the sodium adducts of the 2aminobenzamide-labelled glycans $\mathrm{Man}_{3}$ GlcNAcFucGlcNAc and XylMan ${ }_{2}$ GlcNAcFucGlcNAc, respectively. The oligosaccharide structure with Fuc but lacking Xyl is rarely found on plant glycoproteins and it is interesting to note that it is restricted to only one glycosylation site of cardosin A. It is posssible that the CA31 site is less accessible and thus the xylosyltransferase is prevented from acting.

Aspartic proteinases have various physiological roles, e.g. chymosin and pepsin are digestive enzymes (Davies, 1990), renin participates in the regulation of blood pressure (Galen et al., 1979), cathepsin D (Metcalf and Fusek, 1993), yeast proteinase A (Meussdoerffer et al., 1980), retroviral proteinases (Davies, 1990) and probably also HvAP (Runeberg-Roos et al., 1994) are involved in the processing of protein precursors. Many of these proteins contain one or more $\mathrm{N}$-linked glycans. However, the importance of glycosylation for the activity, specificity and function of aspartic proteinases is not well understood. Some aspartic proteinases have industrial application in cheese production due to their specific cleavage of $\kappa$-casein, e.g. chymosin from the stomach of suckling calves (Berka et al., 1991), Mucor rennin (Aikawa et al., 1990) and cardosin A (Macedo et al., 1993). When bovine chymosin was expressed in Aspergillus niger it was observed that the introduction of a glycosylation site improved either its secretion or stability. However, if hyperglycosylation occurred due to the glycosylation characteristics of the host, the proteolytic activity of the enzyme was decreased (Berka et al., 1991). The examination of electron density maps from a preliminary X-ray diffraction analysis of cardosin A crystals (Frazão, C., 1996, unpublished results) led to the assignment of both glycosylation sites (Asn70 and Asn363). Both sites are away from the aspartic proteinase catalytic site and from the specificity determining cleft. Therefore, it is unlikely that the oligosaccharides will play a dramatic role in the activity and specificity of the enzyme although they may act to stabilize the protein conformation.

We thank Christiane Proppe for technical assistance, Farid Khan for the tobacco $\beta$-xylosidase and Dr Terry Butters for the jack bean $\alpha$-mannosidase. This work was supported by Junta Nacional de Investigação Cientifica e Tecnológica (Portugal) projects PRAXIS/2/2.1/QUI/17/94 and PBIC/C/BIO/1277/92, grant BPD/4154/94 to J. C. A. W was supported by the National Cancer Institute Department of Health and Human Services (USA) contract with $\mathrm{ABL}$ and J. K. had a grant from the Academy of Finland. The Plant Glycoprotein Research Facility at York is supported by the Biotechnology and Biological Sciences Research Council and Oxford GlycoSystems.

\section{REFERENCES}

Aikawa, J., Yamashita, T., Nishiyama, M., Horinouchi, S. \& Beppu, T. (1990) Effects of glycosylation on the secretion and enzyme activity of Mucor rennin, an aspartic proteinase of Mucor pusillus, produced by recombinant yeast, J. Biol. Chem. 265, 13955-13959.

Asakura, T., Watanabe, H., Abe, K. \& Arai, S. (1995) Rice aspartic proteinase, oryzasin, expressed during seed ripening and germination, has a gene organization distinct from those of animal and microbial aspartic proteinases, Eur. J. Biochem. 232, 77-83.

Ashford, D., Dwek, R. A., Welply, J. K., Amatayakul, S., Homans, S. W., Lis, H., Taylor, G. N., Sharon, N. \& Rademacher, T. W. (1987) The $\beta 1$-2-D-xylose and $\alpha 1$-3-L-fucose substituted N-linked oligosaccharides from Erythrina cristagalli lectin, Eur. J. Biochem. 166, $311-320$.

Bensadoun, A. \& Weinstein, D. (1976) Assay of proteins in the presence of interfering materials, Anal. Biochem. 70, 241-250.

Berka, R. M., Kodama, K. H., Rey, M. W., Wilson, L. J. \& Ward, M. (1991) The development of Aspergillus niger var. awamori as a host for the expression and secretion of heterologous gene products, Biochem. Soc. Trans. 19,681-685. 
Bigge, J. C., Patel, T. P., Bruce, J. A., Goulding, P. N., Charles, S. M. \& Parekh, R. B. (1995) Nonselective and efficient fluorescent labeling of glycans using 2-aminobenzamide and anthranilic acid, Anal. Biochem. 230, 229-238.

Cordeiro, M. C., Xue, Z., Pietrzak, M., Pais, M. S. \& Brodelius, P. E. (1994) Isolation and characterization of a cDNA from flowers of Cynara cardunculus encoding cyprosin (an aspartic proteinase) and its use to study the organ-specific expression of cyprosin, Plant Mol. Biol. 24, 733-741.

Davies, D. R. (1990) The structure and function of the aspartic proteinases, Annu. Rev. Biophys. Chem. 19, 189-215.

Edge, A. S. B., Faltynek, C. R., Hof, L., Reichert, L. E. \& Weber, P. (1981) Deglycosylation of glycoproteins by trifluoromethanesulfonic acid, Anal. Biochem. 118, 131-137.

Faye, L. \& Chrispeels, M. J. (1985) Characterization of N-linked oligosaccharides by affinobloting with concanavalin A-peroxidase and treatment of the blots with glycosidases, Anal. Biochem. 149, $218-$ 224.

Galen, F., Devaux, C., Guyenne, T., Menard, J. \& Corvol, P. (1979) Multiple forms of human renin, J. Biol. Chem. 254, 4848-4855.

Grabenhorst, E., Hofer, B., Nimtz, M., Jäger, V. \& Conradt, H. S. (1993) Biosynthesis and secretion of human interleukin 2 glycoprotein variants from baculovirus-infected Sf21 cells, Eur. J. Biochem. 215, $189-197$.

Guruprasad, K., Törmäkangas, K., Kervinen, J. \& Blundell, T. L. (1994) Comparative modelling of barley-grain aspartic proteinase: a structural rationale for observed hydrolytic specificity, FEBS Lett. 352, $131-136$.

Hase, S., Koyama, S., Daiyasu, H., Takemoto, H., Hara, S., Kobayashi, Y., Kyogoku, Y. \& Ikenaka, T. (1986) Structure of a sugar chain of a protease inhibitor isolated from barbados pride (Caesalpinia pulcherrima sw) seeds, J. Biochem. (Tokyo) 100, 1-10.

Hori, H., Yoshino, T., Ishizuka, Y., Yamauchi, T. \& Murakami, K. (1988) Role of $\mathrm{N}$-linked oligosaccharides attached to human renin expressed in COS cells, FEBS Lett. 232, 391-394.

Laemmli, U. K. (1970) Cleavage of structural proteins during the assembly of the head of the bacteriophage T4, Nature $227,680-685$.
Macedo, I. Q., Faro, C. J. \& Pires, E. (1993) Specificity and kinetics of the milk-clotting enzyme from cardoon (Cynara cardunculus L.) towards bovine $\kappa$-casein, J. Agric. Food Chem. 41, 1537-1540.

Metcalf, P. \& Fusek, M. (1993) Two crystal structures for cathepsin D: the lysosomal targeting signal and active site, EMBO J. 12, 12931302.

Meussdoerffer, F., Tortora, P. \& Holzer, H. (1980) Purification and properties of proteinase A from yeast, J. Biol. Chem. 255, 12087-12093.

Montreuil, J., Bouquelet, S., Debray, H., Fournet, B., Spit, G. \& Strecker, G. (1986) Glycoproteins, in Carbohydrate analysis (Chaplin, M. F. \& Kennedy, J. F., eds) pp. 143-204, IRL Press, Oxford.

Ponting, C. P. \& Russell, R. B. (1995) Swaposins: circular permutations within genes encoding saposin homologues, Trends Biochem. Sci. $20,179-180$.

Runeberg-Roos, P., Kervinen, J., Kovaleva, V., Raikhel, N. V. \& Gal, S. (1994) The aspartic proteinase of barley is a vacuolar enzyme that processes probarley lectin in vitro, Plant Physiol. 105, 321-329.

Runeberg-Roos, P., Törmäkangas, K. \& Östman, A. (1991) Primary structure of a barley-grain aspartic proteinase, Eur. J. Biochem. 202, $1021-1027$.

Sarkkinen, P., Kalkkinen, N., Tilgmann, C., Siuro, J., Kervinen, J. \& Mikola, L. (1992) Aspartic proteinase from barley grains is related to mammalian lysosomal cathepsin D, Planta 186, 317-323.

Tarentino, A. L. \& Plummer, T. H. (1982) Oligosaccharide accessibility to peptide: $\mathrm{N}$-glycosidase as promoted by protein-unfolding reagents, J. Biol. Chem. 257, 10776-10780.

Törmäkangas, K., Kervinen, J., Östman, A., Teeri, T. (1994) Tissuespecific localization of aspartic proteinase in developing and germinating barley grains, Planta 195, 116-125.

Van Kuik, J. A., Hoffmann, R. A., Mutsaers, J. H. G. M., Vanhalbeek, H., Kamerling, J. P. \& Vliegenthart, J. F. G. (1986) H-1-NMR structural-reporter-groups of fucose $\alpha-(1-3)$-linked to asparagine-bound $\mathrm{N}$-acetylglucosamine, Glycoconj. J. 3, 27-34.

Veríssimo, P., Faro, C., Moir, A. J. G., Lin, Y., Tang, J. \& Pires, E. (1996) Purification, characterization and partial amino acid sequencing of two new aspartic proteinases from fresh flowers of Cynara cardunculus L., Eur. J. Biochem. 235, 762-768. 